\title{
Maternal low protein diet leads to placental angiogenic compensation via dysregulated M1/M2 macrophages and TNF $\alpha$ expression in Sprague-Dawley rats
}

Running Title: LP diet induces placental angiogenic dysregulation

Keywords: iNKT cells; angiogenesis; fibroblast growth factor; M1 and M2 macrophages; low protein diet

Emilie Vomhof-DeKrey ${ }^{\mathrm{ab}}$, Diane Darland ${ }^{\mathrm{c}}$, Othman Ghribi ${ }^{\mathrm{d}}$, Amy Bundy $^{\mathrm{a}}$, James Roemmich $^{\mathrm{a}}$, Kate Claycombe ${ }^{\mathrm{a}}$ ${ }^{a}$ USDA -ARS, Human Nutrition Research Center, Grand Forks, ND 58203

${ }^{b}$ University of North Dakota, School of Medicine and Health Sciences, Department of Surgery, Grand Forks, ND 58202

'University of North Dakota, School of Medicine and Health Sciences, Department of Biology, Grand Forks, ND 58202

${ }^{\mathrm{d} U n i v e r s i t y ~ o f ~ N o r t h ~ D a k o t a, ~ S c h o o l ~ o f ~ M e d i c i n e ~ a n d ~ H e a l t h ~ S c i e n c e s, ~ D e p a r t m e n t ~ o f ~ B a s i c ~}$ Sciences, Grand Forks, ND 58202

Grant Support: This work was funded by USDA Agricultural Research Service Project \#306251000-052-00D. The contents of this publication do not necessarily reflect the views or policies of the United States Department of Agriculture or the Agricultural Research Service, nor does mention of trade names, commercial products, or organizations imply endorsement from the U.S. government. USDA is an equal opportunity provider and employer.

Conference Presentation: Presented in part at the Experimental Biology Meeting, March 27 April 1, 2015, Boston, MA.

${ }^{\mathrm{b}}$ Correspondence:

Kate J. Claycombe, Ph. D, USDA-ARS, Grand Forks Human Nutrition Research Center 2420 2nd Ave. N., Grand Forks, ND 58203

Phone: 701-795-8298

Fax: 701-795-8230

e-mail: kate.claycombe@ ars.usda.gov 


\begin{abstract}
A maternal low-protein (LP) diet in Sprague-Dawley rats results in low birth weight, rapid adipose tissue catch-up growth, adult obesity, and insulin resistance. The placenta functions to fulfill the fetus' nutrient demands. Adequate angiogenic factor concentrations help to ensure normal growth and vasculature development of the placenta and, in turn, optimum maternal-tofetal nutrient delivery. Maternal malnutrition creates a proinflammatory environment that leads to inhibition of placental tissue growth. Therefore, we hypothesized that a maternal LP diet will lead to abnormal angiogenesis via dysregulation of immune cells resulting in increased secretion of proinflammatory cytokines and reduced angiogenic factor expression. Sprague-Dawley dams were fed $8 \%$ LP or $20 \%$ normal protein diets for 3 weeks prior to breeding and throughout pregnancy. Placenta from dams fed a LP diet weighed less; had increased M2 macrophages producing TNF $\alpha$, decreased M1 macrophages and iNKT cells; greater angiogenic factor (FGF2, VEGFR-1, IGF2) expression and protein content, and greater CD31/PECAM (platelet endothelial cell adhesion molecule) expression. Prenatal protein restriction may induce the placenta to upregulate compensatory mechanisms of angiogenesis in order to meet the nutrient demands of the fetus.
\end{abstract}




\section{Introduction}

We have shown that a maternal low protein (LP) diet reduces the birth weight of male offspring which leads to rapid adipose tissue growth, adult-onset weight gain, and an increased risk of insulin resistance (Claycombe et al., 2015b, Claycombe et al., 2013a). Normal development of the fetus resulting in normal birthweight depends on adequate placental function (Anderson et al., 2005, Ouyang et al., 2013a, Murphy et al., 2006). Throughout gestation, the placental size gradually increases and is correlated with nutrient transfer capacity, which is especially important in the third trimester as this is the developmental period of the most rapid fetal growth. Placental dysfunction due to an increase in inflammation and/or immune dysfunction could lead to placental cell injury (Ouyang et al., 2013b). However, it is not yet known whether a maternal LP diet affects placental immune function and inflammatory responses and whether this is connected with reduced birth weight.

Pregnancy is considered an inflammatory state due to the activation of maternal leukocytes and increased acute phase reactants (i.e. C-reactive protein, complement factors, serum amyloid A) and proinflammatory cytokines (Brown et al., 2014, Challier et al., 2008, Hauguel-de Mouzon and Guerre-Millo, 2006). Macrophages are one of the major immune cell types that regulate the inflammatory response during pregnancy (Nagamatsu and Schust, 2010). Placental macrophages originate from both fetal (Hofbauer cells from fetal chorionic villi) as well as from maternal sources (decidual macrophages of the maternal decidua basalis) (PinhalEnfield et al., 2012).

Macrophages differentiate from monocytes that infiltrate the placental tissue from circulation. These cells activate into two major subphenotypes based on their local environment (Brown et al., 2014, Nagamatsu and Schust, 2010). M1 type (proinflammatory) macrophages are 
polarized by toll-like receptor 4 agonists such as lipopolysaccharide, IFN $\gamma$, TNF $\alpha$, and GM-CSF. M1 macrophages secrete proinflammatory cytokines such as IL-12, IL-23, TNF $\alpha$, and reactive oxygen species. Conversely, macrophages that are stimulated with IL-4, IL-10, IL-13, IL-33, TGF $\beta$ and/or M-CSF will form M2 type (anti-inflammatory) macrophages with an increased expression of mannose and scavenger receptors and produce anti-inflammatory cytokines such as IL-10 and TGF $\beta$ (Brown et al., 2014). M2 macrophages have a wide range of functions, so they have been further subdivided into M2a (IL-4 and IL-13 induced), M2b (exposed to immune complexes and toll-like receptor agonists), and M2c (IL-10 and glucocorticoid hormone induced) (Brown et al., 2014, Mantovani et al., 2004). M2a cells exhibit the alternatively active phenotype typically attributed to M2 cells. M2b cells have a Type II phenotype as they promote T-cell helper 2 responses and are able to produce both pro- and anti-inflammatory cytokines such as, TNF $\alpha$, IL-1, IL-6, IL-10 ${ }^{\text {high }}$, and IL-12 ${ }^{\text {low }}$. M2c cells produce extracellular matrix components, IL-10, and TGF- $\beta$ (Brown et al., 2014, Mantovani et al., 2004).

In addition to macrophages being key players in inflammatory processes, they are also important in promoting angiogenesis by producing pro-angiogenic cytokines such as TNF $\alpha$ and growth factors such as vascular endothelial growth factor (VEGF) and basic fibroblast growth factor 2 (FGF2) (Jetten et al., 2014). These pro-angiogenic properties are not shared by all subsets of macrophages as these angiogenic factors are more highly expressed by M2 rather than M1 macrophages. The ability of the M2 macrophages to express these pro-angiogenic factors provides them the ability to mediate each phase of the angiogenic cascade, including endothelial cell proliferation and migration and formation of vascular sprouts (Jetten et al., 2014). Taken together, we hypothesize that a maternal LP diet leads to reduced placental tissue growth due to a dysregulation of growth factors and M1 and M2 macrophage populations, and an increase in 
proinflammatory cytokines that promote angiogenic factors and compensatory angiogenesis to try to supply the fetuses with adequate nutrition.

\section{Methods}

\section{Study design and animals}

Obese-prone Sprague-Dawley female rats (Charles River, Wilmington, MA) were fed an AIN93-based diet containing either $8 \%$ (low protein, LP) or $20 \%$ protein (normal protein, NP) starting 2 weeks prior to breeding and throughout pregnancy (Claycombe et al., 2015a, Claycombe et al., 2013b, Claycombe et al., 2015b). Male breeders were fed a normal chow diet. Placentas were harvested at day 19 or day 20 of gestation, which is late in the $3^{\text {rd }}$ trimester when the greatest fetal growth occurs (Baumrucker and Stover, 1987). Dam euthanasia was by $\mathrm{CO}_{2}$ inhalation according to animal use and care protocol approved by the USDA ARS Animal Care and Use Committee guidelines. Harvested placental tissues were either immediately frozen in liquid nitrogen or single-cell suspensions were prepared.

\section{Tissue collection and flow cytometry}

Single cell suspensions were prepared from placenta or spleen by mashing through a 100 $\mu \mathrm{m}$ sieve and a plunger from a $3 \mathrm{ml}$ syringe in complete media (RPMI, 10\% fetal bovine serum, 1\% L-glutamine, 10mM HEPES, 1x penicillin/streptomycin, $0.1 \%$ beta-mercaptoethanol). These single cell suspensions of placental cells, (Hauguel-de Mouzon and Guerre-Millo, 2006) from the stromal vascular fraction (SVF) or splenocytes were treated with one or two successive RBC lysis (Sigma-Aldrich, St. Louis, MO) treatments and filtering through a $100 \mu \mathrm{m}$ sieve. Subcutaneous adipose tissue was minced and digested using collagenase type I (Sigma Aldrich, 
St. Louis, MO) at $37^{\circ} \mathrm{C}$, shaking for 1 hour. Adipose tissue cells were filtered using $100 \mu \mathrm{m}$ nylon cell strainers (Fisher, Pittsburgh, PA). The subcutaneous adipose SVF cells were separated from floating primary adipocytes by centrifugation $(500 \mathrm{xg}, 5 \mathrm{~min})$. SVF cell pellet was treated with RBC lysis buffer for 5 min at room temperature, quenched with DMEM $+10 \%$ FBS and centrifuged. Splenocytes, subcutaneous SVFs or placental SVFs were stained with monoclonal antibodies for surface markers and intracellular markers for flow cytometry as stated in the supplemental methods.

\section{Real-time qPCR}

Total RNA was extracted using the RNeasy Lipid Tissue Mini kit and Qiacube (Qiagen, Valencia, CA) from whole, flash-frozen placental tissue or from single cell suspensions (as described above) of placental SVF cells, splenocytes and subcutaneous adipose SVF cells or splenocytes. Collected mRNA was converted to cDNA using the Quantitect Reverse Transcriptase kit (Qiagen, Valencia, CA) and then used to measure expression of genes in Supplemental Table 1 by qPCR (ABI Prism 7500 PCR System, Applied Biosystems, Foster City, CA). FastStart Universal Probe Master mix assay reagents were purchased from Roche (Indianapolis, IN). Primers were purchased from Integrated DNA Technology (IDT, Coralville, IA). The endogenous control (18S rRNA) was purchased from Applied Biosystems.

\section{Western Immunoblotting}

Protein $(25 \mu \mathrm{g})$ from isolated placenta tissue was suspended in $2.5 \mu$ l of loading sample buffer and 1M DTT and run by electrophoresis on a 10\% Bis-Tris gel (Life Technologies). Protein was transferred to a PVDF membrane, washed, and hybridized with primary FGF-basic 
antibody or primary VEGF antibody and primary $\alpha$ Tubulin antibody as a loading reference (Abcam, Cambridge, MA) at $4^{\circ} \mathrm{C}$ overnight. The membrane was washed with $1 \mathrm{X}$ PBS containing $0.1 \%$ Tween and hybridized with secondary antibody for $1 \mathrm{hr}$ in $0.1 \%$ Tween and 0.01\% SDS buffer. Images were developed using an Odyssey Infrared Imager (Li-Cor Biosciences Inc., Lincoln, NE).

\section{Immunohistochemistry}

Placenta tissue was collected and immediately frozen in liquid nitrogen prior to cryosectioning at $10 \mu \mathrm{m}$ thickness. Sections were air dried and post-fixed in 3.7\% paraformaldehyde in phosphate buffered saline (PBS) for 10 minutes at room temperature (RT). For standard histological staining, slides were stained with Hematoxylin Solution Gill \#2 (Sigma-Aldrich, St. Louis, MO) for 2 minutes, run through tap water and $0.05 \%$ Eosin Y in acidified alcohol solution (Sigma) for 1 minute each, passed through an alcohol dehydration series prior to a $2 \mathrm{X}$ 2-minute exposure to xylene and then mounted with Permount ${ }^{\mathrm{TM}}$ solution (Vector Labs, Burlingame, CA). For immunolabeling, sections were blocked with 3\% donkey serum, $2 \%$ bovine serum albumin, and $0.1 \%$ TritonX-100 in PBS overnight at $4^{\circ} \mathrm{C}$ in a moist chamber. Sections were labeled with CD31 antibody directly conjugated to phycoerythrin (Novusbio Inc., Littleton, CO; $10 \mu \mathrm{g} / \mathrm{ml}$ ) and 4',6-diamidino-2-phenylindole (DAPI, Sigma; 2 $\mu \mathrm{g} / \mathrm{ml}$ ) diluted in block solution for one hour at RT then washed 3 X 10 minutes with PBS and mounted with Vectashield mounting medium (Vector Labs). Stained sections were visualized using brightfield or fluorescent microscopy as appropriate on an Olympus BX51WI fluorescent scope and images processed using Adobe Photoshop (Version CS6 Extended, Adobe Systems, Incorporated) with scale bar magnifications listed in the figure legends. 


\section{Statistics}

Quantitative PCR data are reported as fold change of the means \pm standard error of the mean (SEM). GraphPad PRISM5 software was used for unpaired two-tailed t-tests. Statistical significance was set at $\mathrm{p} \leq 0.05$.

\section{Results}

\section{Effects of maternal LP diet on placental weight.}

Previously, we have shown that a maternal LP diet leads to a reduced offspring birth weight followed by rapid adipose tissue growth (refs). As the placenta is the primary mediator of the exchange of nutrients, wastes, and respiratory gases from the mother to the fetus, we wanted to assess whether a maternal LP diet affects placental growth, the placental immune cell environment, and placental vascular development. Placenta weight was lower in the LP group in comparison to the NP group (mean \pm SEM versus mean \pm SEM) (Fig. 1A). There was no group difference in placental efficiency [(ratio of fetus (g)/placenta (g) (Fowden et al., 2009)] between the means of the two groups (mean \pm SEM versus mean \pm SEM). (Fig. 1B).

\section{Placental angiogenic factors FGF2, VEGFR1, and IGF2 increase with a maternal LP diet.}

In an effort to determine the factors associated with a decrease in placental weight due to a maternal LP diet, we analyzed a number of placental growth and angiogenic factors. Angiogenesis is regulated by the pro-angiogenic factors, FGF2 and VEGF (Reynolds and Redmer, 2001). FGF2 protein levels were greater in the LP than NP group (Fig. 2A). There was no difference in VEGF protein between groups (Fig. 2B). The mRNA expression of additional 
pro-angiogenic factors such as VEGF receptor-1 (VEGFR1), VEGFR2, angiopoietin -1 (ANG1), ANG2, angiopoietin tyrosine kinase receptor (Tie2) and insulin-like growth factor -2 (IGF2), were measured and only mRNA levels of VEGFR1 and IGF2 were greater in the LP than NP group (Fig. 2C). It is plausible that the greater expression of angiogenesis factors in maternal LP placentas was due to a compensatory increase in vascularization in an attempt to counter the decreased amount of placental tissue in an attempt to maintain the genetically programmed rate offetal growth (Vaswani et al., 2013).

\section{The angiogenesis inducer, TNF $\alpha$, is upregulated in maternal LP placentas.}

We next evaluated whether a change in the inflammatory environment of the LP placentas was occurring concurrently with the reduction in placental weight. There were no differences in the mRNA expression levels of IL-12, IL-6, IL-10, or IL-1 $\beta$ between the LP and NP diet groups; however, a placental TNF $\alpha$ mRNA expression was greater in maternal LP placenta (Fig. 3). The increase in TNF $\alpha$ is in agreement with previous reports demonstrating an increased secretion of macrophage-derived TNF $\alpha$ during angiongenesis of the cornea. (Klagsbrun and D'Amore, 1991) (Add REF Leibovich, 1987).

\section{Maternal low protein diet increases placental M2 and decreases M1 macrophage proportions.}

Macrophages are one of the major types of immune cells within the placenta and are known to promote angiogenesis (Jetten et al., 2014, Leibovich et al., 1987, Nagamatsu and Schust, 2010). mRNA markers for M1 and M2 macrophages were evaluated by qPCR and macrophage populations were tested by flow cytometry. mRNA expression of CD206 (Mrc1) 
and CD301 (Mg11) were measured as markers for M2 macrophages and CD274 and Nos2 as markers for M1 macrophages. For the M2 macrophage markers, the mRNA expression levels of CD301 were greater in LP than NP placental tissue (Supp. Fig. 1). There was a trending increase in CD206 in LP placenta tissue. There were no group differences in the M1 markers of CD274 or Nos2. In support of the M2 marker mRNA data, the $\% \mathrm{M} 2$ macrophages $\left[\mathrm{CD} 68^{+} \mathrm{CD} 11 \mathrm{c}^{+}\right.$ $\mathrm{CD} 163^{+}$(Bain et al., 2013, Thomsen LH, 2015, Wentworth et al., 2010, Svensson et al., 2011)] of the total $\mathrm{CD} 68^{+}$macrophages (Fig. 4A, B) were greater in placenta of the LP group. The \% 11 macrophages $\left(\mathrm{CD}^{+} 8^{+} \mathrm{CD} 11 \mathrm{c}^{+} \mathrm{CD} 163^{-}\right)$were lower in placental SVFs from dams on a LP diet than on a NP diet (Fig. 4C). Since the flow cytometry plots indicated that the M2 macrophages were expressing CD11c (Fig. 4A), which is typically a marker of M1 macrophages, it was hypothesized that the rat placental $\mathrm{CD} 68^{+} \mathrm{CD} 11 \mathrm{c}^{+} \mathrm{CD} 163^{+}$macrophages are “intermediate” M2-like macrophages (Thomsen LH, 2015), similar to macrophage populations observed in human decidual and adipose tissues (Svensson et al., 2011, Wentworth et al., 2010). Macrophages from human decidual tissue shows properties of M2 and M1 macrophages and produce IL-6, TNF $\alpha$, and CCL4 (Svensson et al., 2011); therefore, some have described them as intermediate M2-like macrophages (Thomsen LH, 2015). It has yet to be confirmed that these intermediate M2-like macrophages could actually be classified (Svensson et al., 2011) as M2a, M2b, or M2c (Brown et al., 2014, Mantovani et al., 2004).

Additionally, intracellular staining of the macrophages indicated that the M2 macrophages where producing most of the TNF $\alpha$ of the total placental macrophages by flow cytometry analysis. The $\% \mathrm{M} 2 \mathrm{TNF} \alpha^{+}$macrophages (of the total $\mathrm{CD}^{+} 8^{+} \mathrm{TNF}^{+}$macrophages) were greater in the placentas from dams on the LP diet whereas the $\% \mathrm{M} 1 \mathrm{TNF}^{+}$macrophages (of the total $\mathrm{CD} 68^{+} \mathrm{TNF} \alpha^{+}$macrophages) were lower in the LP group (Fig. 4D, E). mRNA 
expression of GM-CSF from placenta tissue was measured since TNF $\alpha$ induces GM-CSF

expression during angiogenesis (Klagsbrun and D'Amore, 1991, Ribatti, 2014). Placentas from a maternal LP diet group had greater mRNA expression of GM-CSF (Fig. 4F).

\section{Maternal LP diet decreases placental iNKT cell numbers}

Invariant NKT cells are innate $\mathrm{T}$ lymphocytes that respond rapidly to glycolipid antigens by secreting copious amounts of Th1, Th2, and Th17 cytokines in response to glycolipids presented by the CD1d molecule on antigen presenting cells (Bendelac et al., 2007, Kronenberg and Gapin, 2002). Human decidua contains villous and extravillous trophoblasts that express CD1d, which mediates antigen presentation to iNKT cells (Iwasawa et al., 2012, Jenkinson et al., 1999, Matsumoto et al., 2008, Uemura et al., 2008). Activated decidual iNKT cells secrete IFN $\gamma$ and GM-CSF, whereas peripheral blood iNKT cells exhibit a Th2 cytokine bias of IL-4 production during pregnancy (Boyson et al., 2002). Additionally, iNKT cells inhibit tumor angiogenesis via IFN $\gamma$ (Hayakawa et al., 2002). Therefore, it was predicted that consumption of a LP diet would reduce the number of placental iNKT cells. We first evaluated the number of iNKT cells by flow cytometry from dams on a NP diet in the placenta tissue in comparison to collected splenocytes and subcutaneous adipose SVF cells as this has not yet been evaluated in rats. There were fewer iNKT cells in the placenta than in the spleen or subcutaneous adipose SVF (Fig. 5A, B). There were a lower numbers of iNKT cells from the LP placentas (Fig. 5C). mRNA expression of placental IFN $\gamma$ was trending lower in the LP group.

\section{Maternal LP diet increases placental tissue density and CD31/PECAM expression}


In order to confirm increased angiogenesis in LP placentas, frozen placental tissue was sectioned and stained with Gill's Hematoxylin/Eosin (H/E) staining and angiogenic/blood vessel marker, CD31/PECAM (platelet endothelial cell adhesion molecule) (Uras et al., 2012) H/E staining reveals a greaterdensity of the spongiotrophoblast (sp) and labyrinth layers of the LP placentas (Fig. 6). Additionally, the giant cell (gc) layer beneath the labyrinth layer is dense with matrix and additional cells in the LP placentas. Staining with CD31/PECAM also consistently showed a greater density of the spongiotrophoblast layer in the LP placentas (Fig. 7A-D). The maternal decidua or stromal layer (st) did not differ between the LP and NP placentas (Fig. 7A, B). The giant cell layer below the labyrinth layer is denser with cells in the LP placentas as seen through the nuclei DAPI stain; these cells are not positive for CD31/PECAM in this region of the placenta (Fig. 7A-D). Lastly, there is a striking increase in the cell density and vascular organization of the CD31/PECAM ${ }^{+}$cells in the labyrinth layer of the LP placentas (Fig. 7 E, F).

\section{Discussion}

A maternal LP diet leads to a decrease in birth weight, rapid adipose tissue catch-up growth during adolesence, adult-onset weight gain, and increased insulin resistance (Claycombe et al., 2013b, Claycombe et al., 2015b). For the current study, we hypothesized that these consequences of a maternal LP diet were a result of placental dysfunction mediated by an increased pro-inflammatory environment within the placenta that alters the number and function of resident immune cells, reduces placental growth, and produces compensatory increases angiogenic factors and angiogenesis. Indeed, a maternal LP diet decreased placental weight. The angiogenic factors FGF2, VEGFR2, and IGF2 were increased in the LP group placentae as a possible means of compensating for the fetus not receiving enough nutrients from a maternal LP 
diet. There was an increase in pro-angiogenic M2, TNF $\alpha$-producing macrophages and a decrease in anti-angiogenic iNKT cells in the LP placentas. Lastly, immunohistochemistry staining with $\mathrm{H} / \mathrm{E}$ and CD31/PECAM, revealed that LP placentas have an increase in vasculature as measured by an increase in cell density and increased CD31/PECAM ${ }^{+}$cells. These data suggest that decreased maternal dietary protein availability produces compensatory increases in angiogenic factors in an attempt to meet fetal nutrient demands (Fig. 8). However, the offspring of the dams fed a maternal LP diet have a decreased birth weight, so it seems that the angiogenic compensation does not fully overcome the decrease in available protein of the LP diet. The litter size of dams fed a LP diet is not different from dams fed a NP diet so the angiogenic compensation is allowing for a similar number of viable, albeit lower weight, offspring.

Data from our study suggests that a maternal LP diet in Sprague-Dawley rats decreases placental weight. Other maternal LP diet studies have observed a decrease in placental weight (Fowden et al., 2009, Roberts et al., 2001). Our current observation of a decrease in placental weight agrees with our previous results that a maternal LP diet leads to a reduction in offspring birth weight and rapid adipose tissue growth in adolescence (Claycombe et al., 2013b, Claycombe et al., 2015b).

Our data from a rat model regarding how maternal nutrition may induce angiogenesis via inflammatory molecule signalling is in agreement with studies of other species. Specifically, mRNA expression and protein levels of FGF2 are increased in the endometrium in heifer cows fed a lower (protein $10 \%$ of dry matter) protein diet in comparison to lactating cows fed a greater (18\% protein of dry matter) percentage protein diet (Pretheeban et al., 2011). Likewise, pregnant mice fed a protein deficient diet displayed an increased FGF2 concentration in the amniotic fluid (Starr et al., 2015). Complicated pregnancies involving intrauterine growth 
restriction have increased vasculogenesis, angiogenesis, and pseudovasculogenesis via the increased expressions of VEGF-A, FGF2, and eNOS (Barut et al., 2010). Herr and colleagues have demonstrated a role for IGF2 in angiogenesis in that IGF2 increased vessel formation and promoted migration of endothelial cells. IGF2 also induced VEGF mRNA and protein expression in human hepatoma cells (Herr et al., 2003). In the current study, FGF2, VEGFR-1, and IGF2 expression were increased in placentas from LP fed dams. These increases suggest that in utero, protein under-nutrition triggers adaptive mechanisms to circumvent the growth restriction by increasing placental growth/angiogenic factors. However, it appears that the decreased nutrition of the maternal LP diet cannot be completely compensated for by increasing placental growth/angiogenic factors and as a result the placental and fetal weights remain lower in comparison to the placenta and fetus from dams fed a maternal NP diet.

The present study also demonstrated an increase in placental TNF $\alpha$ mRNA levels, an increase in M2 macrophages expressing TNF $\alpha$, and a decrease in iNKT cells. These data agree with one of the first papers describing macrophage induced angiogenesis via TNF $\alpha$, that being in the rat cornea (Leibovich et al., 1987). Yoshida et al. demonstrated that TNF $\alpha$ secreted from macrophages stimulates stromal and vascular endothelial cell expression of IL-8, VEGF, FGF2 and their respective receptors (IL-8R, VEGFR-1, VEGFR-2, FGFR-1) (Yoshida et al., 1997). The secretion of these angiogenic factors by vascular endothelial cells acts as an autocrine loop for angiogenesis as they then continue to promote the secretion of TNF $\alpha$ by macrophages (Yoshida et al., 1997) (Fig.6). Lastly, Jetten et al. demonstrated that M2 macrophages are the subset that induces angiogenesis (Jetten et al., 2014). FGF2 signaling pathways are utilized by M2a macrophages while placental growth factor (PlGF) signaling pathways are utilized by M2c macrophages to induce tube formation during angiogenesis (Jetten et al., 2014). Our data show 
an increase in FGF2 protein level in the placenta and an increase in M2 macrophages expressing TNF $\alpha$. Therefore, we could speculate that a maternal low protein diet stimulates an increase in M2a macrophages that are utilizing FGF2 and TNF $\alpha$ signaling pathways to promote angiogenesis in the placenta. Future research should consider testing LP diet-induced alterations in placental concentrations of tissue factor (TF), an inflammatory mediator (Chu, 2005, Kislinger et al., 2001), and whether inhibition of TF reduces TNF $\alpha$ and VEGF concentrations, resulting in reduced inflammation-induced angiogenesis.

Invariant NKT cells inhibit tumor-induced angiogenesis mediated by IFN $\gamma$ production. It is proposed that the IFN $\gamma$ inhibits tumor-induced angiogenesis by suppressing the expression of angiogenic factors by tumor cells or by inducing production of antiangiogenic factors by the tumor or host stroma cells (Hayakawa et al., 2002). Our data show that a maternal LP diet decreases iNKT cell numbers, which would reduce its ability to inhibit angiogenesis.

With LP placentas showing greater FGF2, VEGFR1, IGF2, M2 $\mathrm{TNF}^{+}$macrophages and reduced iNKT cells, we utilized immunohistochemistry to visualize whether there was an increase in angiogenesis in the LP placental tissue. H/E staining showed an increase in density and cell number in the labyrinth, spongiotrophoblast, and giant cell layers of the placenta (Fig. 6). In Figure 7, angiogenic/vessel cell marker CD31/PECAM staining [staining per (Uras et al., 2012)] also demonstrated an increase in vasculature in these placental cell layers as well. Another study demonstrated an increase in barrier thickness or spongiotrophoblast layer after guinea pigs were fed a food restrictive diet of $70 \%$ of the control. This also led to reduced placental and fetal weights (Roberts et al., 2001). Ewes fed a 60\% restricted diet exhibited greater placental vascularity compared to control animals (Belkacemi et al., 2010) Lastly, two studies utilizing Wistar rats demonstrated that a low-protein diet resulted in a smaller 
vasodilatory response even though there was greater vasculature in the placenta (Koumentaki et al., 2002, Itoh et al., 2002). Therefore, these data suggest that even with greater vasculature in the placenta, the vessels do not function properly which would result in poor nutrient exchange between the mother and fetus.

In conclusion, a maternal LP diet is accompanied by morphological changes to the placenta that result in compensatory alterations that may help to minimize fetal growth restriction. However, even with the increase in angiogenic factors of FGF2, VEGFR-1, IGF2, M2 macrophages producing $\mathrm{TNF} \alpha$, and vasculature, placental function is not normalized since offspring weight is still decreased. The inappropriate placental expression of angiogenic factors contributes to placental vascular defects and apparent placental dysfunction, which contributes to fetal growth retardation (Reynolds and Redmer, 2001, Itoh et al., 2002, Wentworth et al., 2010, Koumentaki et al., 2002). Ultimately, a LP maternal diet affects the placental histomorphology which conclusively contributes to placental function (Belkacemi et al., 2010).

\section{Conflict of Interest}

The authors have no conflict of interest.

\section{Acknowledgements}

Authors are grateful to Phillip Blomberg, and James Lindlauf for providing technical assistance and data organization. This work was funded by USDA Agricultural Research Service Project \#3062-51000-052-00D.

\section{References}


ANDERSON, C. M., LOPEZ, F., ZHANG, H. Y., PAVLISH, K. \& BENOIT, J. N. 2005. Reduced uteroplacental perfusion alters uterine arcuate artery function in the pregnant Sprague-Dawley rat. Biology of reproduction, 72, 762-6.

BAIN, C. C., SCOTT, C. L., URONEN-HANSSON, H., GUDJONSSON, S., JANSSON, O., GRIP, O., GUILliAMS, M., MALISSEN, B., AGACE, W. W. \& MOWAT, A. M. 2013. Resident and pro-inflammatory macrophages in the colon represent alternative contextdependent fates of the same Ly6Chi monocyte precursors. Mucosal Immunol, 6, 498-510.

BARUT, F., BARUT, A., GUN, B. D., KANDEMIR, N. O., HARMA, M. I., HARMA, M., AKTUNC, E. \& OZDAMAR, S. O. 2010. Intrauterine growth restriction and placental angiogenesis. Diagn Pathol, 5, 24.

BAUMRUCKER, C. R. \& STOVER, R. 1987. Rat placentae gamma-glutamyltransferase activity changes during pregnancy. Biology of the neonate, 51, 340-5.

BELKACEMI, L., NELSON, D. M., DESAI, M. \& ROSS, M. G. 2010. Maternal undernutrition influences placental-fetal development. Biology of reproduction, 83, 325-31.

BENDELAC, A., SAVAGE, P. B. \& TEYTON, L. 2007. The biology of NKT cells. Annu Rev Immunol, 25, 297-336.

BOYSON, J. E., RYBALOV, B., KOOPMAN, L. A., EXLEY, M., BALK, S. P., RACKE, F. K., SCHATZ, F., MASCH, R., WILSON, S. B. \& STROMINGER, J. L. 2002. CD1d and invariant NKT cells at the human maternal-fetal interface. Proceedings of the National Academy of Sciences of the United States of America, 99, 13741-6.

BROWN, M. B., VON CHAMIER, M., ALLAM, A. B. \& REYES, L. 2014. M1/M2 macrophage polarity in normal and complicated pregnancy. Frontiers in immunology, 5, 606.

CHALliER, J. C., BASU, S., BINTEIN, T., MINIUM, J., HOTMIRE, K., CATALANO, P. M. \& HAUGUEL-DE MOUZON, S. 2008. Obesity in pregnancy stimulates macrophage accumulation and inflammation in the placenta. Placenta, 29, 274-81.

CLAYCOMBE, K. J., ROEMMICH, J. N., JOHNSON, L., VOMHOF-DEKREY, E. E. \& JOHNSON, W. T. 2015a. Skeletal muscle Sirt3 expression and mitochondrial respiration are regulated by a prenatal low-protein diet. J Nutr Biochem, 26, 184-9.

CLAYCOMBE, K. J., UTHUS, E. O., ROEMMICH, J. N., JOHNSON, L. K. \& JOHNSON, W. T. 2013a. Prenatal low-protein and postnatal high-fat diets induce rapid adipose tissue growth by inducing Igf2 expression in Sprague Dawley rat offspring. The Journal of nutrition, 143, 1533-9.

CLAYCOMBE, K. J., UTHUS, E. O., ROEMMICH, J. N., JOHNSON, L. K. \& JOHNSON, W. T. 2013b. Prenatal low-protein and postnatal high-fat diets induce rapid adipose tissue growth by inducing Igf2 expression in Sprague Dawley rat offspring. J Nutr, 143, 15339.

CLAYCOMBE, K. J., VOMHOF-DEKREY, E. E., ROEMMICH, J. N., RHEN, T. \& GHRIBI, O. 2015b. Maternal low-protein diet causes body weight loss in male, neonate SpragueDawley rats involving UCP-1-mediated thermogenesis. J Nutr Biochem, 26, 729-35.

FOWDEN, A. L., SFERRUZZI-PERRI, A. N., COAN, P. M., CONSTANCIA, M. \& BURTON, G. J. 2009. Placental efficiency and adaptation: endocrine regulation. J Physiol, 587, 3459-72. 
HAUGUEL-DE MOUZON, S. \& GUERRE-MILLO, M. 2006. The placenta cytokine network and inflammatory signals. Placenta, 27, 794-8.

HAYAKAWA, Y., TAKEDA, K., YAGITA, H., SMYTH, M. J., VAN KAER, L., OKUMURA, K. \& SAIKI, I. 2002. IFN-gamma-mediated inhibition of tumor angiogenesis by natural killer T-cell ligand, alpha-galactosylceramide. Blood, 100, 1728-33.

HERR, F., LIANG, O. D., HERRERO, J., LANG, U., PREISSNER, K. T., HAN, V. K. \& ZYGMUNT, M. 2003. Possible angiogenic roles of insulin-like growth factor II and its receptors in uterine vascular adaptation to pregnancy. The Journal of clinical endocrinology and metabolism, 88, 4811-7.

ITOH, S., BRAWLEY, L., WHEELER, T., ANTHONY, F. W., POSTON, L. \& HANSON, M. A. 2002. Vasodilation to vascular endothelial growth factor in the uterine artery of the pregnant rat is blunted by low dietary protein intake. Pediatric research, 51, 485-91.

IWASAWA, Y., KAWANA, K., FUJII, T., SCHUST, D. J., NAGAMATSU, T., KAWANA, Y., SAYAMA, S., MIURA, S., MATSUMOTO, J., ADACHI, K., HYODO, H., YAMASHITA, T., KOZUMA, S. \& TAKETANI, Y. 2012. A possible coagulationindependent mechanism for pregnancy loss involving beta(2) glycoprotein 1-dependent antiphospholipid antibodies and CD1d. American journal of reproductive immunology, 67, 54-65.

JENKINSON, H. J., WAINWRIGHT, S. D., SIMPSON, K. L., PERRY, A. C., FOTIADOU, P. \& HOLMES, C. H. 1999. Expression of CD1D mRNA transcripts in human choriocarcinoma cell lines and placentally derived trophoblast cells. Immunology, 96, 649-55.

JETTEN, N., VERBRUGGEN, S., GIJBELS, M. J., POST, M. J., DE WINTHER, M. P. \& DONNERS, M. M. 2014. Anti-inflammatory M2, but not pro-inflammatory M1 macrophages promote angiogenesis in vivo. Angiogenesis, 17, 109-18.

KLAGSBRUN, M. \& D'AMORE, P. A. 1991. Regulators of angiogenesis. Annu Rev Physiol, 53, 217-39.

KOUMENTAKI, A., ANTHONY, F., POSTON, L. \& WHEELER, T. 2002. Low-protein diet impairs vascular relaxation in virgin and pregnant rats. Clinical science, 102, 553-60.

KRONENBERG, M. \& GAPIN, L. 2002. The unconventional lifestyle of NKT cells. Nat Rev Immunol, 2, 557-68.

LEIBOVICH, S. J., POLVERINI, P. J., SHEPARD, H. M., WISEMAN, D. M., SHIVELY, V. \& NUSEIR, N. 1987. Macrophage-induced angiogenesis is mediated by tumour necrosis factor-alpha. Nature, 329, 630-2.

MANTOVANI, A., SICA, A., SOZZANI, S., AllAVENA, P., VECCHI, A. \& LOCATI, M. 2004. The chemokine system in diverse forms of macrophage activation and polarization. Trends in immunology, 25, 677-86.

MATSUMOTO, J., KAWANA, K., NAGAMATSU, T., SCHUST, D. J., FUJII, T., SATO, H., HYODO, H., YASUGI, T., KOZUMA, S. \& TAKETANI, Y. 2008. Expression of surface CD1d in the extravillous trophoblast cells of early gestational placenta is downregulated in a manner dependent on trophoblast differentiation. Biochemical and biophysical research communications, 371, 236-41.

MURPHY, V. E., SMITH, R., GILES, W. B. \& CLIFTON, V. L. 2006. Endocrine regulation of human fetal growth: the role of the mother, placenta, and fetus. Endocrine reviews, 27, 141-69. 
NAGAMATSU, T. \& SCHUST, D. J. 2010. The immunomodulatory roles of macrophages at the maternal-fetal interface. Reprod Sci, 17, 209-18.

OUYANG, F., PARKER, M., CERDA, S., PEARSON, C., FU, L., GILLMAN, M. W., ZUCKERMAN, B. \& WANG, X. 2013a. Placental weight mediates the effects of prenatal factors on fetal growth: the extent differs by preterm status. Obesity, 21, 609-20.

OUYANG, F., PARKER, M., CERDA, S., PEARSON, C., FU, L., GILLMAN, M. W., ZUCKERMAN, B. \& WANG, X. 2013b. Placental weight mediates the effects of prenatal factors on fetal growth: the extent differs by preterm status. Obesity (Silver Spring), 21, 609-20.

PINHAL-ENFIELD, G., VASAN, N. \& LEIBOVICH, S. 2012. The Role of Macrophages in the Placenta, Embryology - Updates and Highlights on Classic Topics, Prof. Luis Violoin Pereira (Ed.). InTech.

PRETHEEBAN, T., GORDON, M. B., SINGH, R. \& RAJAMAHENDRAN, R. 2011. Comparison of expression levels of candidate genes in endometrium of dairy heifers and lactating dairy cows. Canadian Journal of Animal Science, 91, 255-264.

REYNOLDS, L. P. \& REDMER, D. A. 2001. Angiogenesis in the placenta. Biology of reproduction, 64, 1033-40.

RIBATTI, D. 2014. The discovery of angiogenic growth factors: the contribution of Italian scientists. Vasc Cell, 6, 8.

ROBERTS, C. T., SOHLSTROM, A., KIND, K. L., EARL, R. A., KHONG, T. Y., ROBINSON, J. S., OWENS, P. C. \& OWENS, J. A. 2001. Maternal food restriction reduces the exchange surface area and increases the barrier thickness of the placenta in the guineapig. Placenta, 22, 177-85.

STARR, L. M., SCOTT, M. E. \& KOSKI, K. G. 2015. Protein deficiency and intestinal nematode infection in pregnant mice differentially impact fetal growth through specific stress hormones, growth factors, and cytokines. The Journal of nutrition, 145, 41-50.

SVENSSON, J., JENMALM, M. C., MATUSSEK, A., GEFFERS, R., BERG, G. \& ERNERUDH, J. 2011. Macrophages at the fetal-maternal interface express markers of alternative activation and are induced by M-CSF and IL-10. Journal of immunology, 187, 3671-82.

THOMSEN LH, R. A. 2015. Polarization of Macrophages in Metabolic Diseases. J Clin Cell Immunol, 6, 313.

UEMURA, Y., SUZUKI, M., LIU, T. Y., NARITA, Y., HIRATA, S., OHYAMA, H., ISHIHARA, O. \& MATSUSHITA, S. 2008. Role of human non-invariant NKT lymphocytes in the maintenance of type $2 \mathrm{~T}$ helper environment during pregnancy. International immunology, 20, 405-12.

URAS, N., OGUZ, S. S., ZERGEROGLU, S., AKDAG, A., POLAT, B., DIZDAR, E. A. \& DILMEN, U. 2012. CD31 and Factor VIII in angiogenesis of normal and pre-eclamptic human placentas. Journal of obstetrics and gynaecology : the journal of the Institute of Obstetrics and Gynaecology, 32, 533-6.

VASWANI, K., HUM, M. W., CHAN, H. W., RYAN, J., WOOD-BRADLEY, R. J., NITERT, M. D., MITCHELL, M. D., ARMITAGE, J. A. \& RICE, G. E. 2013. The effect of gestational age on angiogenic gene expression in the rat placenta. PloS one, 8, e83762.

WENTWORTH, J. M., NASELLI, G., BROWN, W. A., DOYLE, L., PHIPSON, B., SMYTH, G. K., WABITSCH, M., O'BRIEN, P. E. \& HARRISON, L. C. 2010. Pro-inflammatory 
CD11c+CD206+ adipose tissue macrophages are associated with insulin resistance in human obesity. Diabetes, 59, 1648-56.

YOSHIDA, S., ONO, M., SHONO, T., IZUMI, H., ISHIBASHI, T., SUZUKI, H. \& KUWANO, M. 1997. Involvement of interleukin-8, vascular endothelial growth factor, and basic fibroblast growth factor in tumor necrosis factor alpha-dependent angiogenesis. Mol Cell Biol, 17, 4015-23. 


\section{Figure Legends}

Figure 1. Maternal low protein diet decreases placental weight. Placenta tissue was isolated at day 19-20 of gestation. (A) Placenta wet weight was measured in individual weigh boats using an analytical balance; $n=53-69$ placentas of male fetuses, from 10-12 dams. (B) Placental efficiency was calculated as a ratio of grams of fetus (wet weight)/ grams of placenta (wet weight). Significant $*=p \leq 0.05$ between LP and NP.

Figure 2. FGF2 protein expression is increased in placenta from dams on a low protein diet. Placenta tissue was isolated at day 19-20 of gestation. Protein expression of (A) FGF2 and (B) VEGF was determined by western blot. Values are means \pm S.E.M.; $n=7-8$ placentas of male fetuses, from 4 dams. Significant bars $=p \leq 0.05$ between LP and NP. mRNA expression of (C) VEGFR-1, VEGFR-2, ANG-1, ANG-2, Tie2, IGF1, and IGF2 were measured by qPCR and normalized to $18 \mathrm{~S}$ rRNA. Values are means \pm S.E.M.; $n=22-32$ placentas of male fetuses, from 5-6 dams. Significant $*=p \leq 0.05$ between LP and NP.

Figure 3. Increase in pro-inflammatory $\mathrm{TNF} \alpha$ cytokine in the placenta from dams on a low protein diet. Placenta tissue was isolated at day 19-20 of gestation. mRNA expression of TNF $\alpha$, IL-1 $\beta$, IL-6, IL-10, and IL-12 genes were measured by qPCR and normalized to $18 \mathrm{~S}$ rRNA. Values are means \pm S.E.M.; $n=20$-24 placentas of male fetuses, from 5-6 dams. Significant $*=\mathrm{p} \leq 0.05$ between LP and NP. 
Figure 4. Maternal low protein diet increases \%M2 macrophages expressing TNFa. Placenta tissue was harvested at day 19-20 of gestation. (A) FACs plot gating of M1 (Zombie

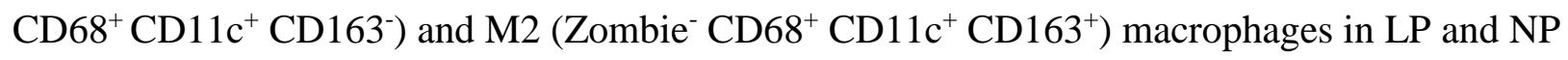
placental SVFs. Previous gate was on Zombie $\mathrm{CD}^{-} 8^{+}$macrophages. (B) Placental \%M2 macrophages (Zombie $\left.\mathrm{CD}^{+} \mathrm{CD}^{+} 1 \mathrm{c}^{+} \mathrm{CD} 163^{+}\right),(\mathrm{C}) \% \mathrm{M} 1$ macrophages (Zombie- $\mathrm{CD}^{+}$

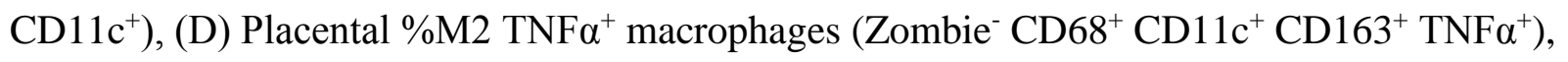
and (E) $\% \mathrm{M} 1 \mathrm{TNF}^{+}$macrophages $\left(\mathrm{Zombie}^{-} \mathrm{CD}^{+} 8^{+} \mathrm{CD} 11 \mathrm{c}^{+} \mathrm{TNF}^{+}\right)$of the total $\mathrm{CD} 68^{+}$ macrophages were measured on a BD Canto II Flow Cytometer; n= 10-18 placentas of male fetuses, from 2-3 dams. (F) GM-CSF mRNA expression was measured by qPCR and normalized to $18 \mathrm{~S}$ rRNA; $\mathrm{n}=20-23$ placentas of male fetuses, from 5-6 dams. Values for all graphs are means \pm S.E.M.; Significant $*=\mathrm{p} \leq 0.05$ between LP and NP.

Figure 5. Maternal low protein diet decreases the number of iNKT cells in the placenta. Spleen, subcutaneous adipose tissue and placenta were harvested at day 19-20 of gestation from dams on a NP diet. (A, B) NP Splenocytes, subcutaneous and placental SVFs were stained for iNKT cell markers (B220- $\mathrm{PI}^{-} \mathrm{TCR} \beta^{+} \mathrm{CD} 1 \mathrm{~d}$ tet $\left.{ }^{+}\right)$and measured on a BD Canto II Flow

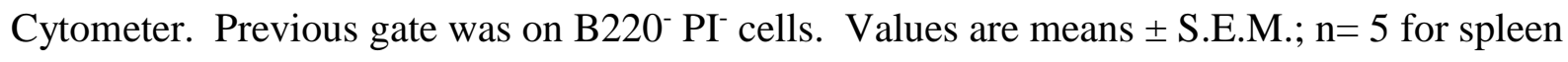
and subcutaneous adipose, $n=38$ for placentas of male and female fetuses, from 5 dams. (C) Numbers of iNKT cells from placenta attached to male fetuses as measured on a BD Canto II Flow Cytometer. Values are means \pm S.E.M.; $n=29-31$ placentas. (D) Placenta tissue mRNA expression of IFN $\gamma$ was measured by qPCR and normalized to $18 \mathrm{~S}$ rRNA. Values are means \pm S.E.M.; $\mathrm{n}=15-24$ placentas of male fetuses, from 5-6 dams. Significant $*=\mathrm{p} \leq 0.05$ between LP and NP. 
Figure 6. LP Placenta tissue density is increased. Frozen placenta tissue was sectioned, fixed with $3.7 \%$ paraformaldehyde in buffered saline, and stained with Gill's Hematoxylin/Eosin staining. Placenta layers- labyrinth layer (lab), spongiotrophoblast layer (sp), giant cell layer (gc) and decidua or stromal layer (st). Low power images on the left provide orientation (scale bar $=500 \mu \mathrm{m})$ with higher power images shown for comparison $($ scale bar $=100 \mu \mathrm{m})$.

Figure 7. Angiogenic marker, CD31/PECAM, is increased in LP placenta. Frozen placenta tissue was sectioned, fixed with $3.7 \%$ paraformaldehyde in buffered saline and labelled with CD31/PECAM (red) and DAPI (blue). (A, B) Spongiotrophoblast (sp), giant cell (gc), and stromal (st) placental layers; scale bar is $100 \mu \mathrm{m}$. (C, D) Spongiotrophoblast, giant cell, and (E, F) labyrinth placental layers; scale bar is $50 \mu \mathrm{m}$.

\section{Figure 8. Hypothetical scheme of maternal low protein diet effect on placental}

dysregulation. A maternal LP diet leads to an increase in angiogenic factors of FGF2, VEGFR1, IGF2, GM-CSF, and M2 macrophages producing TNF $\alpha$. There is also a decrease in the number of iNKT cells which normally inhibit angiogenesis. These data indicate that the placenta may be trying to compensate for the maternal LP diet in order to satisfy the demand of the growing fetus. 


\section{Supplemental Methods}

\section{Flow cytometry}

Splenocytes, subcutaneous SVFs or placental SVFs were stained with the following monoclonal antibodies for flow cytometry: anti-rat CD45R (HIS24), anti-rat alpha beta TCR (R73), and antimouse/rat TNA alpha (TN3-19.12) from eBioscience (San Diego, CA); anti-rat CD11c (8A2), anti-rat CD68 (ED1), and anti-rat CD163 (ED2) from AbD Serotec (Raleigh, NC). Invariant NKT cells were identified with tetramers of rat CD1d- $\alpha$-GalCer (PBS-57; US National Institutes of Health) conjugated to allophycocyanin or phycoerythrin. Intracellular staining of TNF $\alpha$ was performed using the FoxP3/Transcription factor fixation/permeabilization kit from eBioscience. Samples were acquired on a FACSCanto II (BD, San Jose, CA) and were analyzed with FlowJo software (TreeStar, Ashland, OR).

Supplemental Figure 1. Maternal low protein diet increases mRNA markers for M2 macrophages in placental tissue. Placenta tissue was harvested at day 19-20 of gestation. M2 macrophage markers, (A) CD301 (Mg11) and (B) CD206 (Mrc1) and M1 macrophage markers, (C) CD274 (PDL1, programmed death ligand 1) and (D) Nos2 (nitric oxide synthase 2) were measured by qPCR and normalized to $18 \mathrm{~S}$ rRNA. The normalized values were then compared to CD68 (pan-macrophage marker, that was normalized also to 18S rRNA) in order to get a ratio. Values are means \pm S.E.M.; $n=14-24$ placentas of male fetuses. Significant bars $=p \leq 0.05$ between LP and NP. 
Supplemental Figure 2. Increased \%M2 macrophages expressing TNF $\alpha$ in LP placentas

Placenta tissue was harvested at day 19-20 of gestation. (A) FACs plot gating of M1 (Zombie ${ }^{-}$

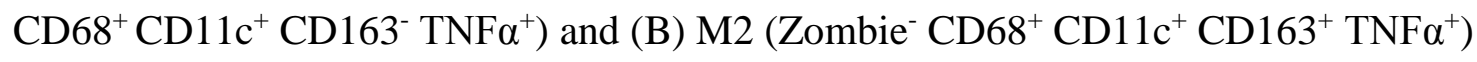

macrophages in LP and NP placental SVFs. Previous gate was on Zombie $\mathrm{CD}^{-} 8^{+}$macrophages; $\mathrm{n}=10-18$ placentas of male fetuses, from 2-3 dams. 
Supplemental Table 1.

\begin{tabular}{|c|c|c|c|}
\hline Gene & Forward Primer & Reverse Primer & Probe \\
\hline CD274 & $\begin{array}{l}\text { CGT CTC CTC GAA CTG } \\
\text { TGT ATC }\end{array}$ & $\begin{array}{l}\text { TCC GTC CTT TTG TTC } \\
\text { CTC ATC }\end{array}$ & $\begin{array}{l}\text { /56-FAM/CGA AGC } \\
\text { CGC/ZEN/ATT TTT CCA CAT } \\
\text { CTA GC/3IABkFQ/ }\end{array}$ \\
\hline Nos2 & $\begin{array}{l}\text { CAG CTT GTC CAG GGA } \\
\text { TTC TG }\end{array}$ & $\begin{array}{l}\text { CTA TTC CCA GCC CAA } \\
\text { CAA CA }\end{array}$ & $\begin{array}{l}\text { /56-FAM/CAT TCT } \\
\text { GTG/ZEN/CAG TCC CAG TGA } \\
\text { GGA A/3IABkFO/ }\end{array}$ \\
\hline CD301/Mgl1 & $\begin{array}{l}\text { CCT TCC TGT GCA ATA } \\
\text { TCC TCT C }\end{array}$ & $\begin{array}{l}\text { TTG TCT AAA GTG GTT } \\
\text { CTC AGG G }\end{array}$ & $\begin{array}{l}\text { /56-FAM/TGC TGC } \\
\text { TGG/ZEN/TGG TTA TCT CCG } \\
\text { TG/3IABkFO/ }\end{array}$ \\
\hline CD206/Mrc1 & $\begin{array}{l}\text { TGG CGA GCA TCA AGA } \\
\text { GTA AAG }\end{array}$ & $\begin{array}{l}\text { ATA GGA AAC AGG AGA } \\
\text { ACC ATC AC }\end{array}$ & $\begin{array}{l}\text { /56-FAM/CCA TAG } \\
\text { GTC/ZEN/AGT CCC AGC CAA } \\
\text { AAC A/3IABkFQ/ }\end{array}$ \\
\hline CD68 & $\begin{array}{l}\text { TGA GAA TGT CCA CTG } \\
\text { TGC TG }\end{array}$ & $\begin{array}{l}\text { CAT TCC CTT ACG GAC } \\
\text { AGC TTA C }\end{array}$ & $\begin{array}{l}\text { /56-FAM/CTC TGA } \\
\text { TGT/ZEN/CGG TCC TGT TTG } \\
\text { AAT CCA/3IABkFQ }\end{array}$ \\
\hline Flt-1/VEGFR-1 & $\begin{array}{l}\text { GGA TCC TCC CAG TCT } \\
\text { CG }\end{array}$ & $\begin{array}{l}\text { GGA GGT AGT GGT GGT } \\
\text { AGT G }\end{array}$ & $\begin{array}{l}\text { /56-FAM/TGC GCT } \\
\text { TGA/ZEN/GTC CCG GAG } \\
\text { C/3IABkFO/ }\end{array}$ \\
\hline Kdr/VEGFR-2 & $\begin{array}{l}\text { GGA TGA GGA TCT TGA } \\
\text { GTT CGG }\end{array}$ & $\begin{array}{l}\text { GAA TCG ACA AGA CAG } \\
\text { CGA CT }\end{array}$ & $\begin{array}{l}\text { /56-FAM/AAG AGG } \\
\text { GAG/ZEN/CAA CAC ACA GCG } \\
\text { A/3IABkFQ/ }\end{array}$ \\
\hline ANG-1 & $\begin{array}{l}\text { GTT GTC GTT ATC AGC } \\
\text { GTC CTT }\end{array}$ & $\begin{array}{l}\text { AGG AAA CCA GAA GCA } \\
\text { GAA CTA C }\end{array}$ & $\begin{array}{l}\text { /56-FAM/ACA GCA } \\
\text { GGC/ZEN/AAA CAG AGC } \\
\text { AGC/3IABkFQ/ }\end{array}$ \\
\hline ANG-2 & $\begin{array}{l}\text { CCA CCA TCT CCT TCT } \\
\text { TCA TGT }\end{array}$ & $\begin{array}{l}\text { CTA CGA CGA CTC AGT } \\
\text { GCA AA }\end{array}$ & $\begin{array}{l}\text { /56-FAM/TGT AGT } \\
\text { TCT/ZEN/CCA GCT TCA TCA } \\
\text { GCC AC/3IABkFQ/ }\end{array}$ \\
\hline Tek/Tie2 & $\begin{array}{l}\text { GCT TCT CAT AGA GTT } \\
\text { CTG CAC A }\end{array}$ & $\begin{array}{l}\text { GTG ATG TAT GGT CCT } \\
\text { ATG GTG T }\end{array}$ & $\begin{array}{l}\text { /56-FAM/AGT GCC } \\
\text { TCC/ZEN/TAA GCT AAC GAT } \\
\text { CTC CC/3IABkFO/ }\end{array}$ \\
\hline TNF $\alpha$ & $\begin{array}{l}\text { GGA AGA TAA CCA GAG } \\
\text { GCA ACA }\end{array}$ & $\begin{array}{l}\text { CTT TCT AAG CGG AAA } \\
\text { TGA GTG C }\end{array}$ & $\begin{array}{l}\text { /56-FAM/ATG AAG } \\
\text { CTG/ZEN/TGC CTA CCT CCA } \\
\text { GTT G/3IABkFQ/ }\end{array}$ \\
\hline IL-10 & $\begin{array}{l}\text { AGC TGA AGA CCC TCT } \\
\text { GGA TAC }\end{array}$ & $\begin{array}{l}\text { TGG CCT TGT AGA CAC } \\
\text { CTT TG }\end{array}$ & $\begin{array}{l}\text { /56-FAM/CGC TGT } \\
\text { CAT/ZEN/CGA TTT CTC CCC } \\
\text { TGT/3IABkFQ/ }\end{array}$ \\
\hline IL-12 & $\begin{array}{l}\text { ACT CCC CAT TCC TAC } \\
\text { TTC TCC }\end{array}$ & $\begin{array}{l}\text { GAT ATT CGC CCC TTT } \\
\text { GCA TTG }\end{array}$ & $\begin{array}{l}\text { /56-FAM/TCC TCC } \\
\text { TCT/ZEN/GTC TCC TTC GTC TTT } \\
\text { TCT T/3IABkFO/ }\end{array}$ \\
\hline IL-6 & $\begin{array}{l}\text { CCT TCT GTG ACT CTA } \\
\text { ACT TCT CC }\end{array}$ & $\begin{array}{l}\text { CAG AGC AAT ACT GAA } \\
\text { ACC CTA GT }\end{array}$ & $\begin{array}{l}\text { /56-FAM/TCC TTC } \\
\text { CTA/ZEN/CCC CAA CTT CCA } \\
\text { ATG C/3IABkFO/ }\end{array}$ \\
\hline IL-1 $\beta$ & $\begin{array}{l}\text { TTG TCG TTG CTT GTC } \\
\text { TCT CC }\end{array}$ & $\begin{array}{l}\text { GTG CTG TCT GAC CCA } \\
\text { TGT }\end{array}$ & $\begin{array}{l}\text { /56-FAM/TGG CTT } \\
\text { ATG/ZEN/TTC TGT CCA TTG } \\
\text { AGG TGG/3IABkFQ/ }\end{array}$ \\
\hline
\end{tabular}




\begin{tabular}{|l|l|l|l|}
\hline IFN & $\begin{array}{l}\text { GAG TTC ATT GAC AGC } \\
\text { TTT GTG C }\end{array}$ & $\begin{array}{l}\text { CGC ACC TGA TCA CTA } \\
\text { ACT TCT }\end{array}$ & $\begin{array}{l}\text { /56-FAM/CAT TCA } \\
\text { TGA/ZEN/GCA TCG CCA AGT } \\
\text { TTCGAG/3IABkFO/ }\end{array}$ \\
\hline IGF2 & $\begin{array}{l}\text { TGT CTC CAG GTG TCG } \\
\text { AAT TTG }\end{array}$ & $\begin{array}{l}\text { GGG ACG TGT CTA CCT } \\
\text { CTC AG }\end{array}$ & $\begin{array}{l}\text { /56-FAM/CCA } \\
\text { ACC/ZEN/CCG TGG GCAAGT } \\
\text { TC/3IABkFO/ }\end{array}$ \\
\hline GM-CSF & AGC TCT GAG CCT CCT & $\begin{array}{l}\text { CCG TAG ACC CTG CTT } \\
\text { GTA TAG }\end{array}$ & $\begin{array}{l}\text { /56-FAM/CAT GTC } \\
\text { GGC/ZEN/CTC TGG ATG GAG } \\
\text { AAC/3IABkFO/ }\end{array}$ \\
\hline
\end{tabular}


Figure 1.
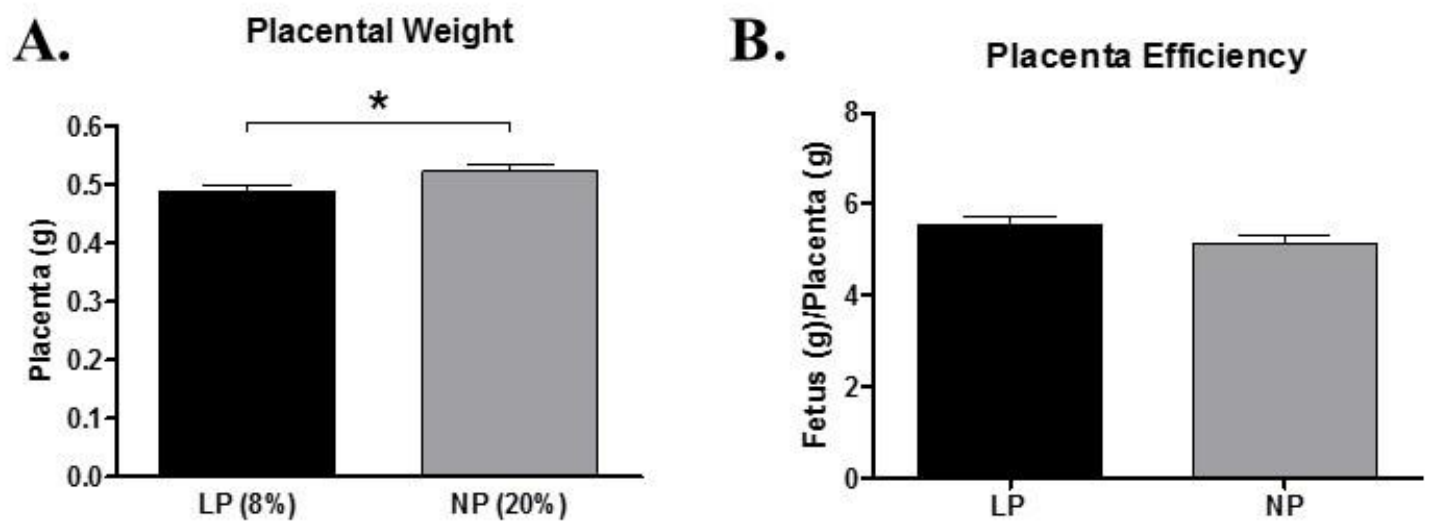
Figure 2.

A.

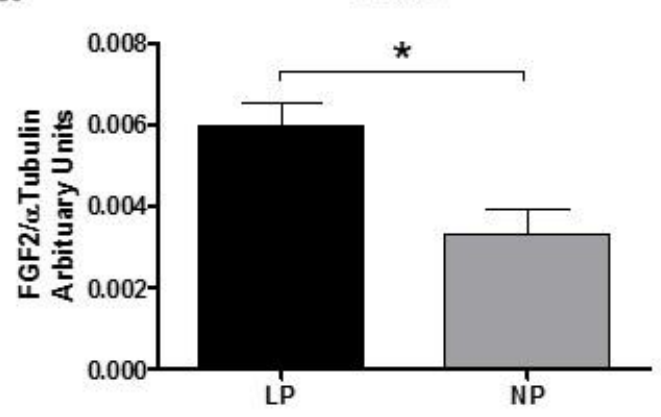

B. VEGF

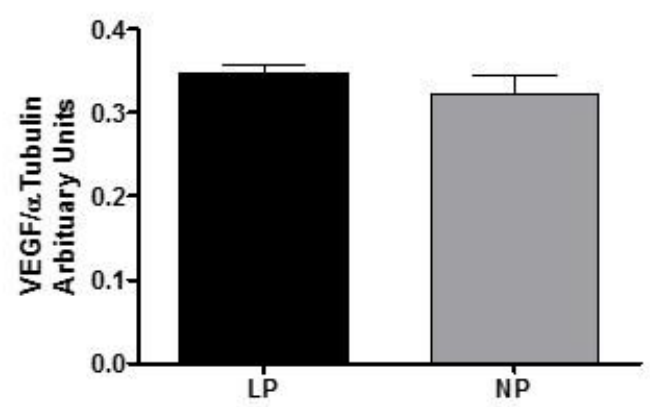

C.

Angiogenesis Factors

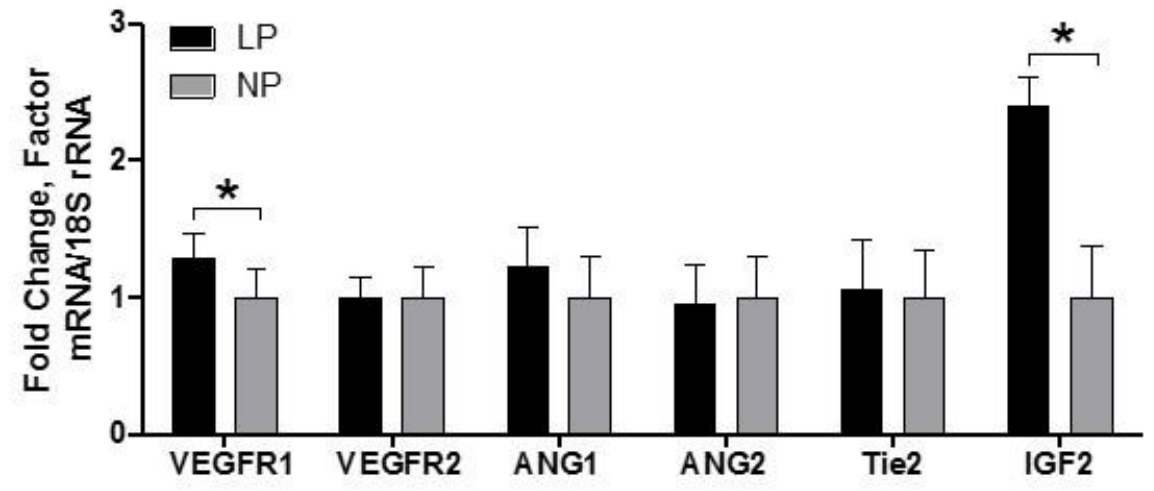


Figure 3.

Cytokines

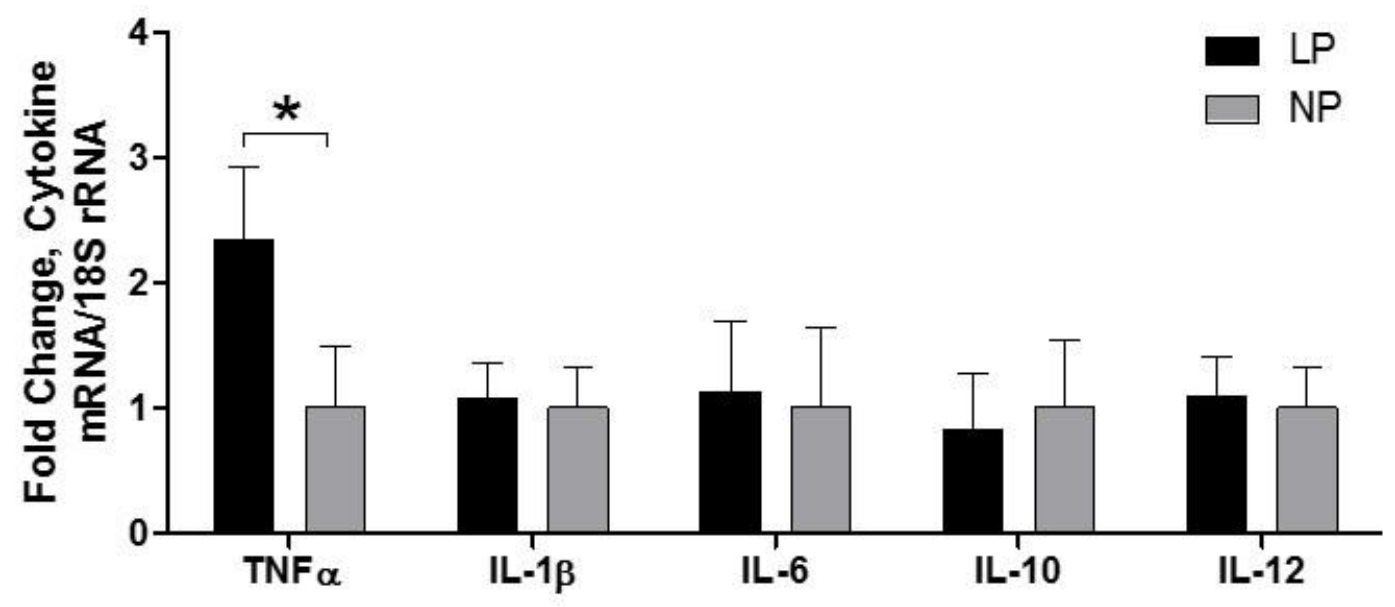


Figure 4.
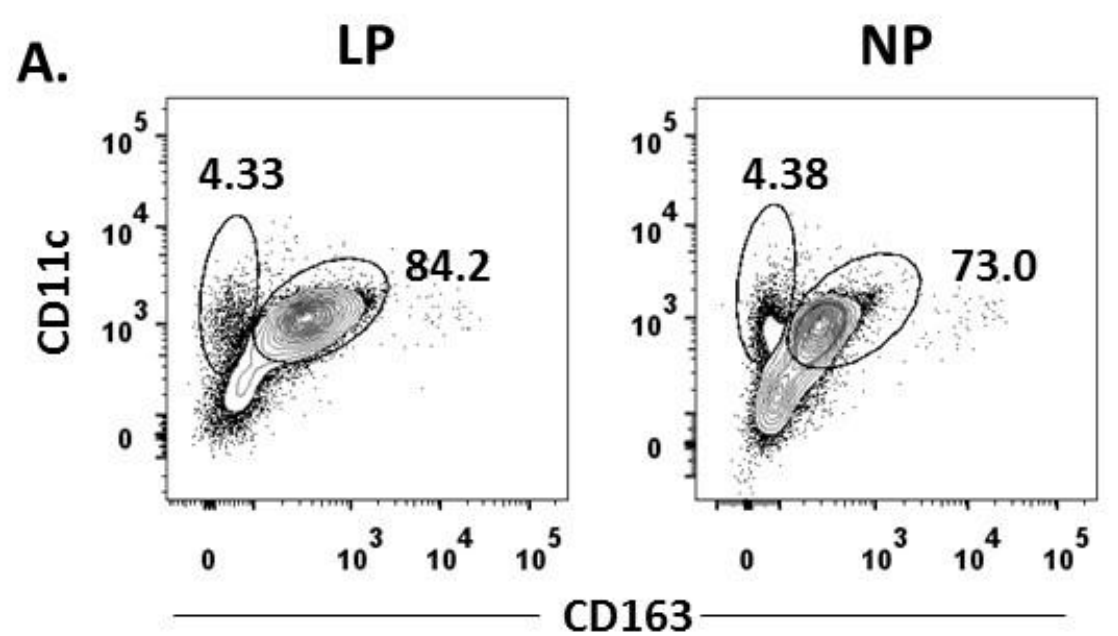

B.

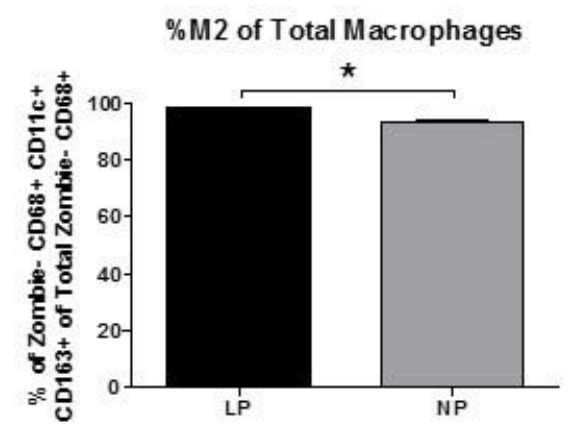

D.

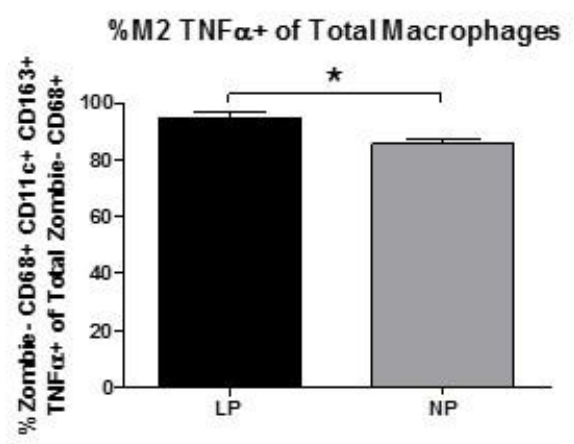

C.

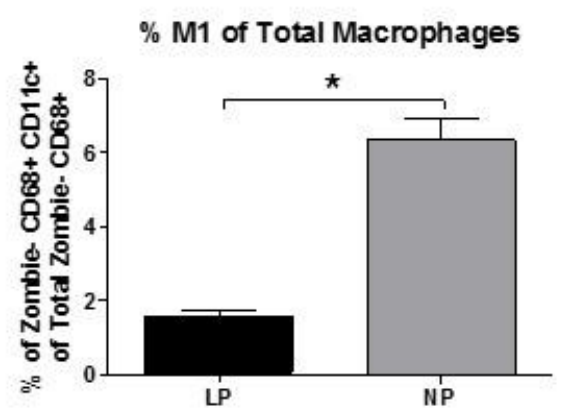

E.

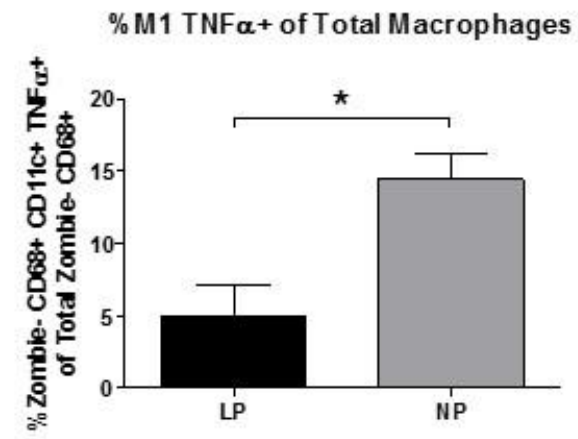

F.

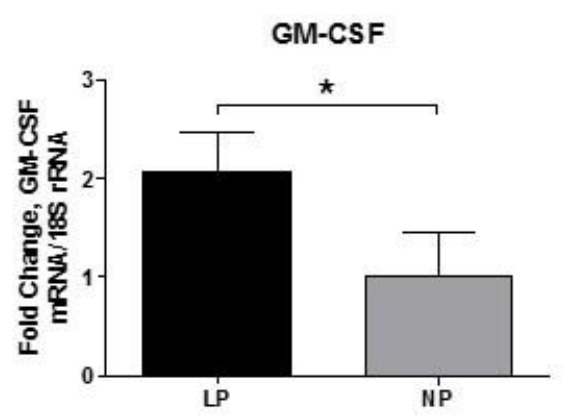


Figure 5.

A.
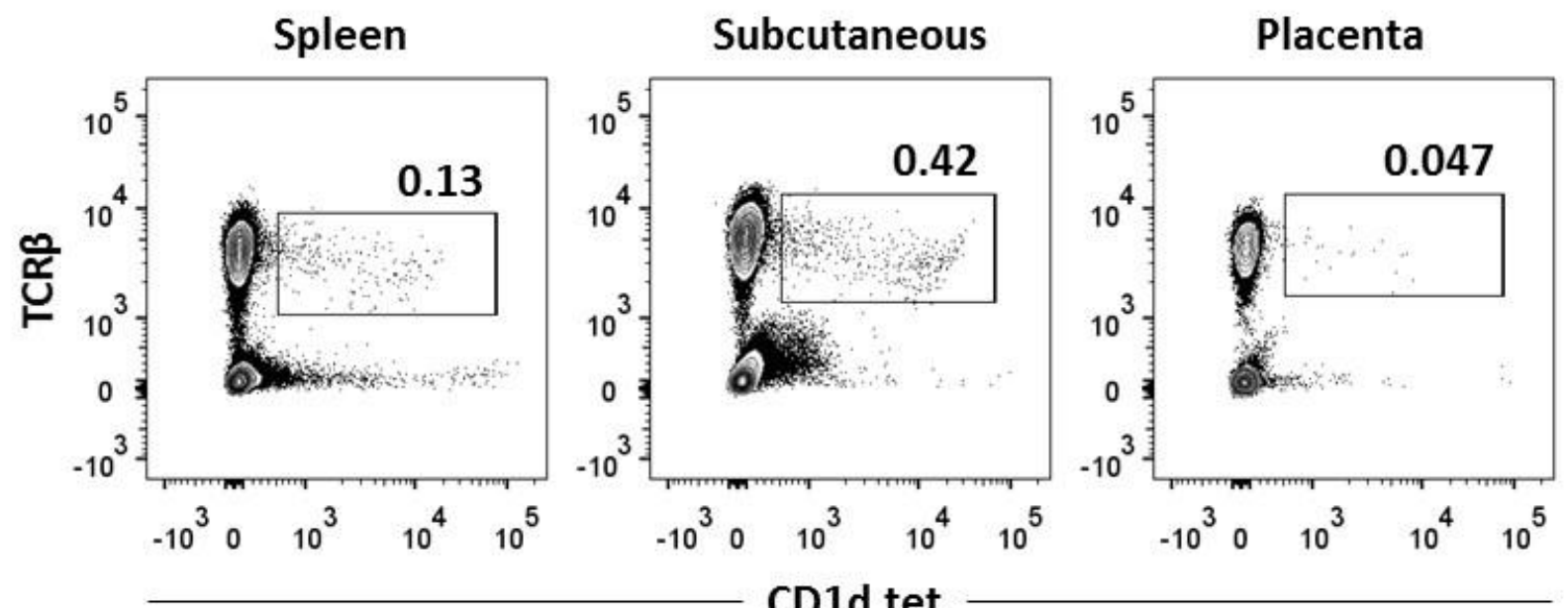

CD1d tet

B.

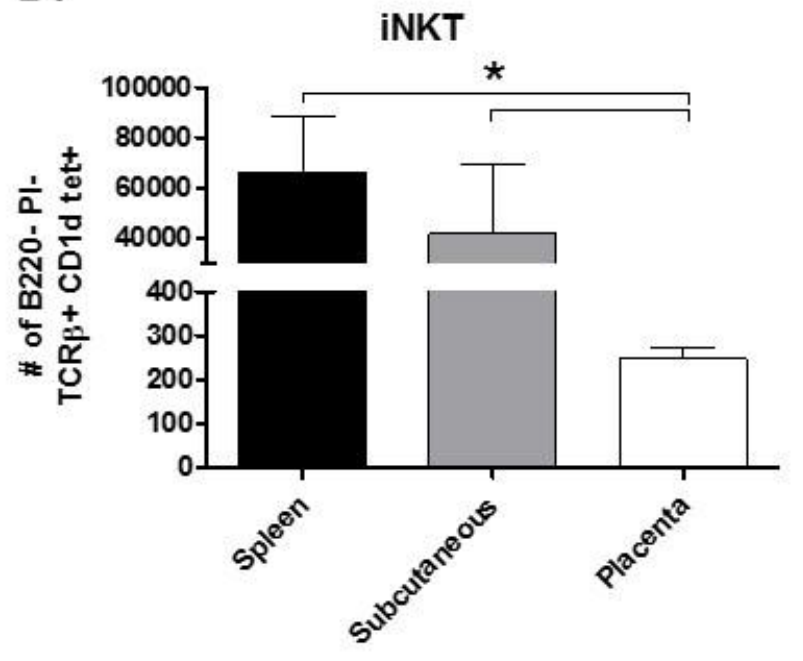

D.

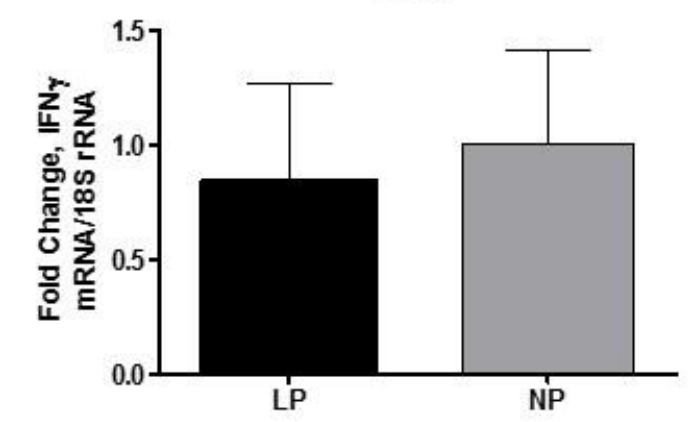

c.

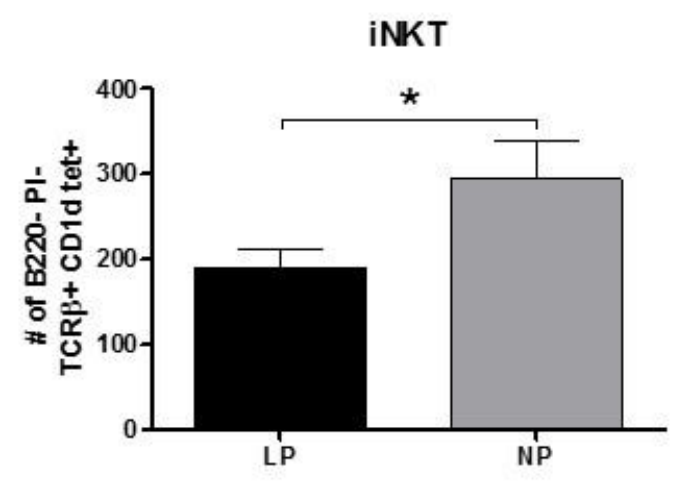


Figure 6.
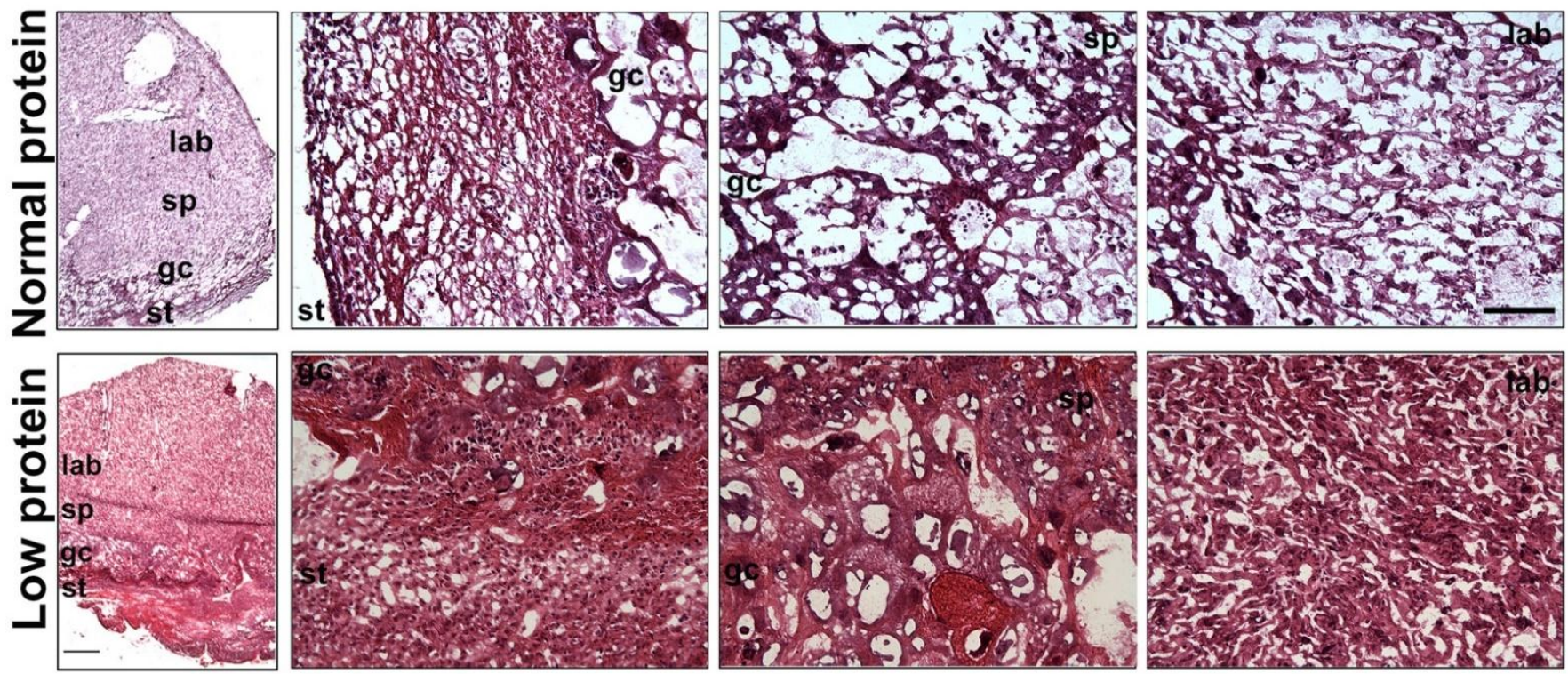
Figure 7.

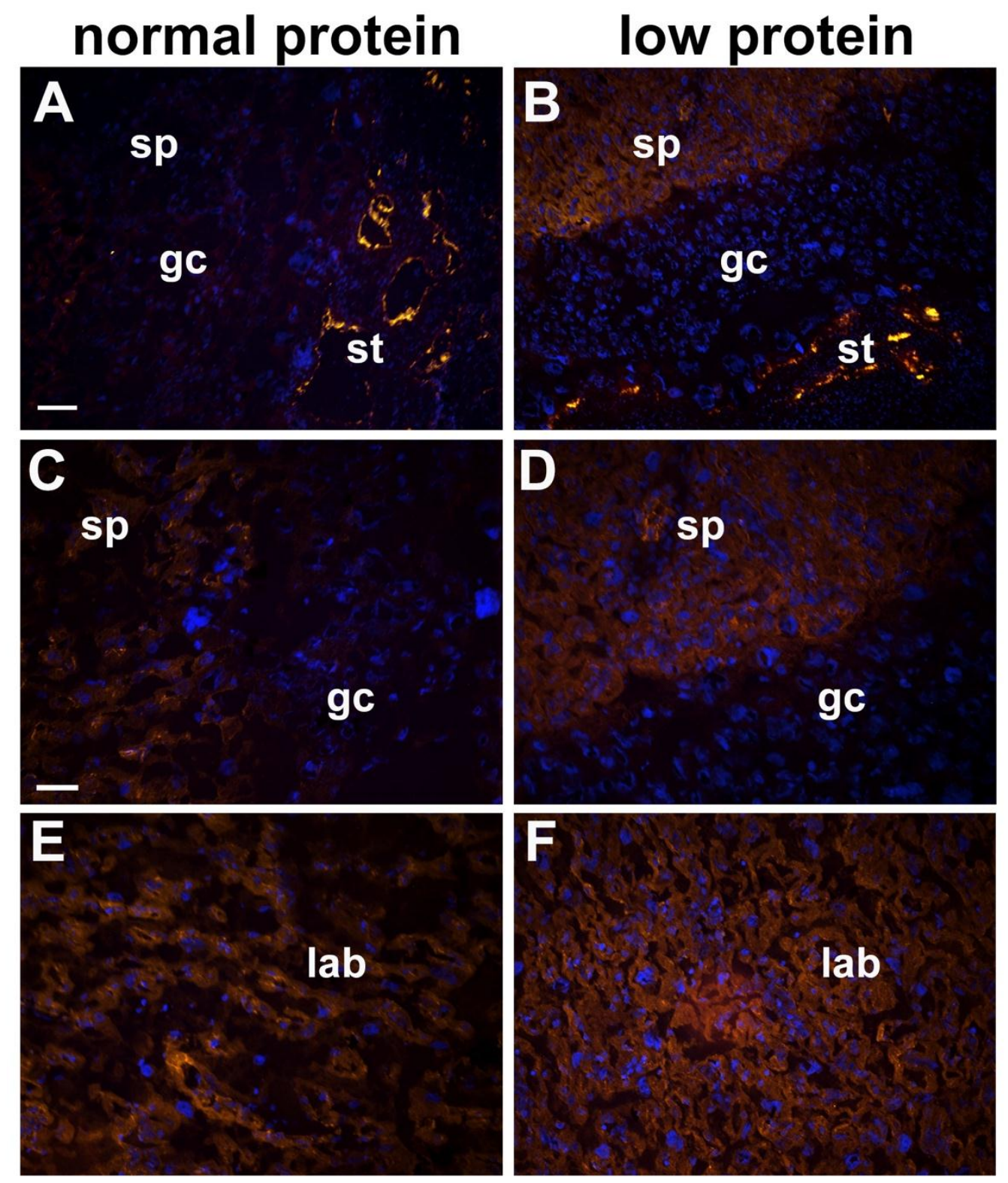


Figure 8.

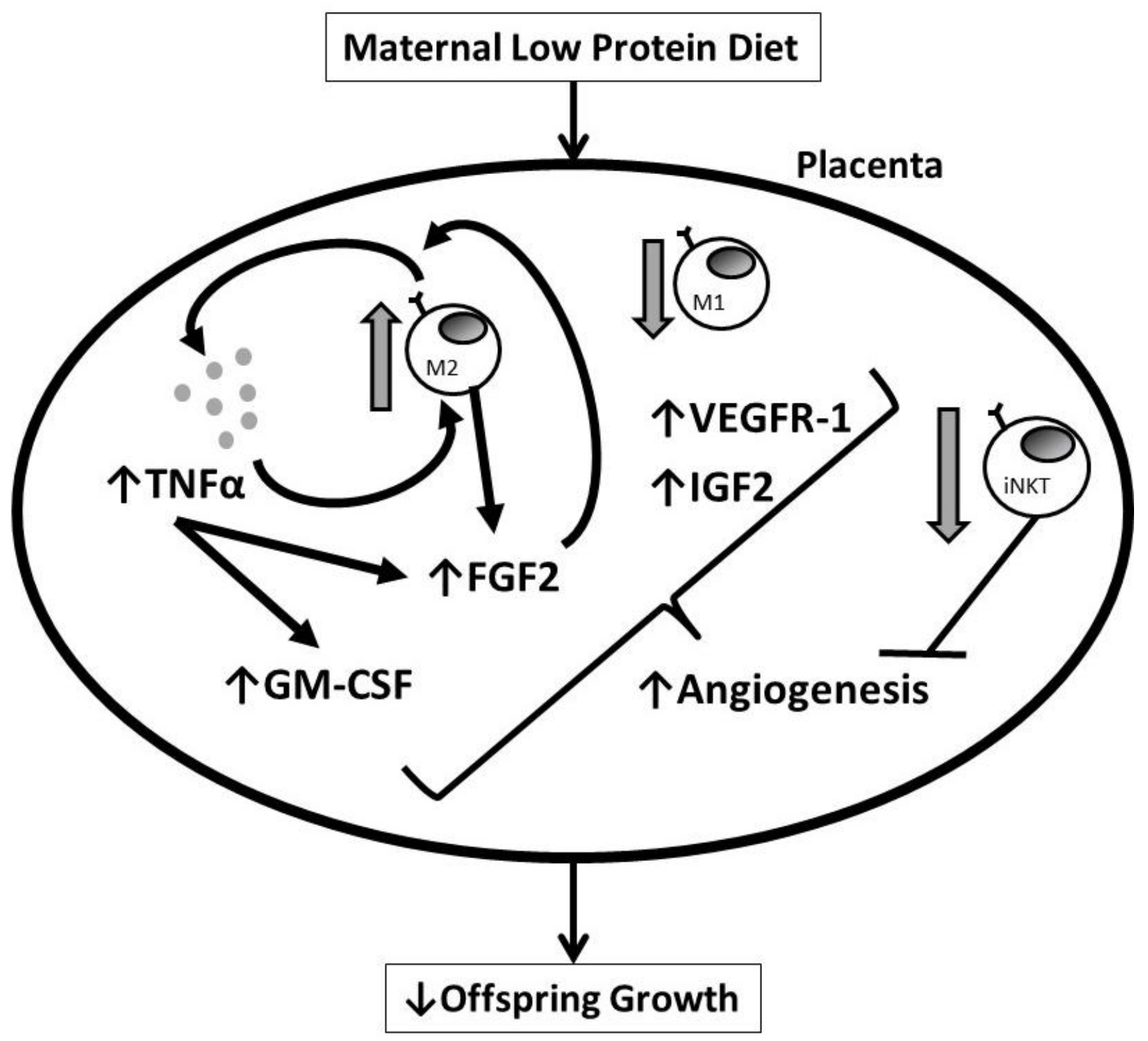


Supplemental Figure 1

A.

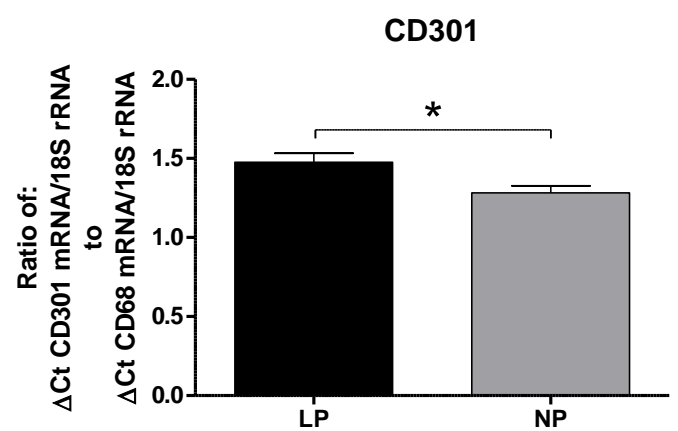

C.

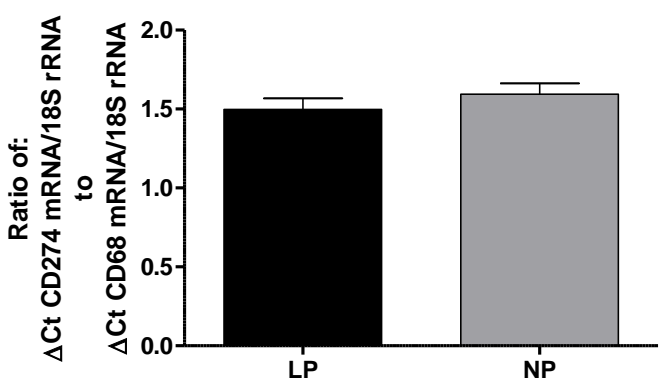

B.

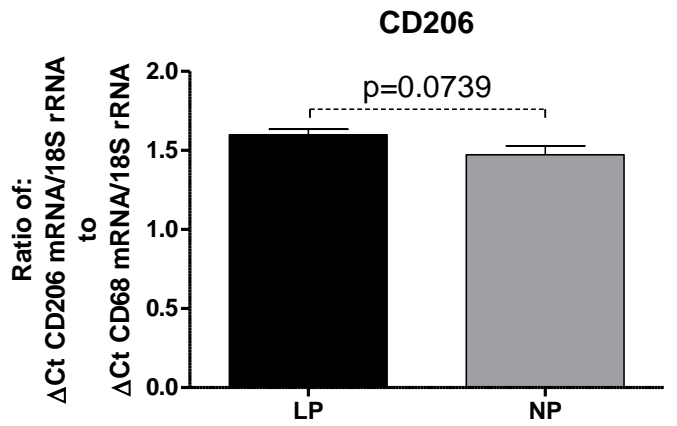

D.

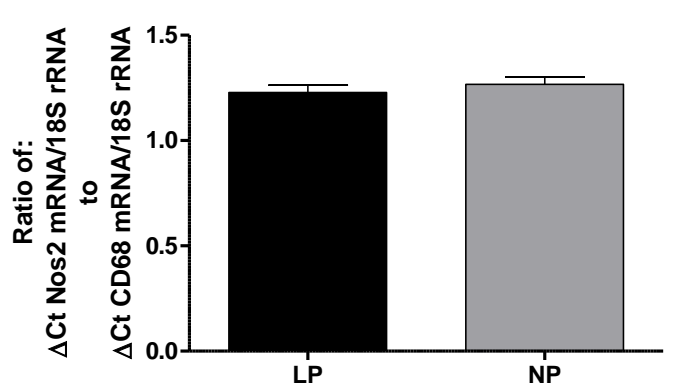


Supplemental Figure 2
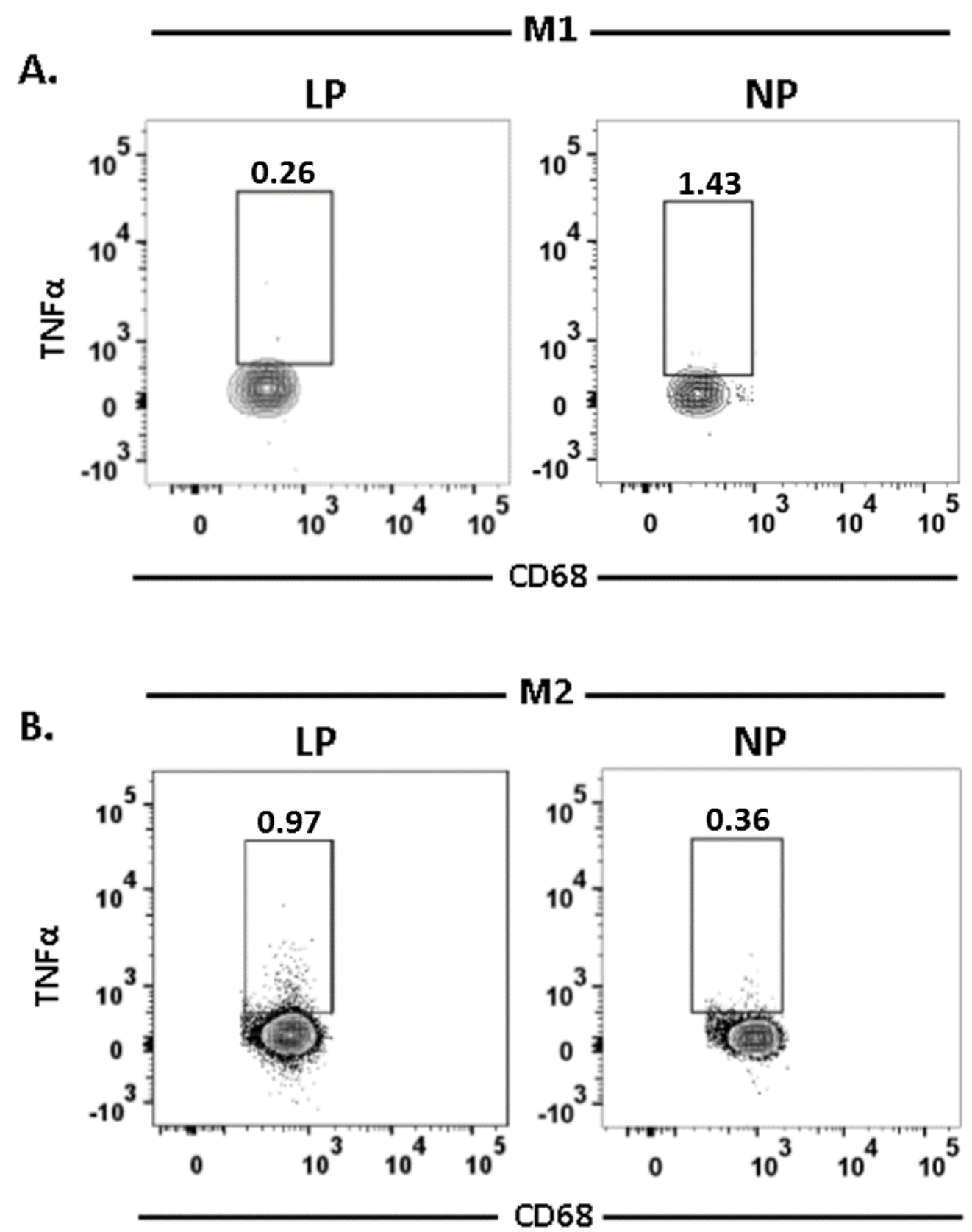